\title{
Novelty of Artistic Forms in Contemporary Lithuanian Architecture
}

\author{
Aušra Černauskienè, Vilnius Gediminas Technical University
}

\begin{abstract}
The article presents an analysis of the concept of novelty of artistic forms and its visual expressions in contemporary Lithuanian architecture. It is stated that the novelty is virtually manifested through utopian visions of the new world and their metamorphoses, and is made relevant by the method of experiment. Based on examples of Western European architectural utopias and experiments, the article suggests the formulated indicators of novelty, which are reflected in artistic forms of contemporary Lithuanian architecture. The aim of the research is to reveal the concept of novelty linking it with transformation and utopia, and illustrating it with the objects of contemporary Lithuanian architecture.
\end{abstract}

Keywords - Artistic form, experiment, metamorphosis, novelty, utopia, virtual.

Since times of Classical Antiquity, there is an idea of existence of the other, perfect, virtual world, the place of residence of the higher power, God. Architecture also has an old tradition to create futuristic architecture, which could stimulate the appearance of new artistic forms in the real, relevant world. An architect visualises his/her images and ideas in sketches, models, computer screen and thus creates still non-existent reality allowing for unfolding the new alternatives from utopian, virtual space. Generating such new creative ideas requires a certain conditioninspiration, energy, rave - manifested through breaking the rules and disruption of the canons. Therefore, novelty in architecture first of all is conveyed through analysis of utopian ideas, which picture a dream, ideal society and alternative architectural forms. Utopian ideas are materialized through experiment and obtain new artistic forms containing certain characteristics and expressions, which are disclosed further in this article presenting the works of contemporary Lithuanian architects as examples. The article focuses on such utopian and experimental ideas, which have positively influenced the future in artistic sense and become a certain creative reference point for further generations of architects.

The present text is a part of broader scientific research, which in its turn analyses the expressions of interaction between new artistic forms and technologies in contemporary Lithuanian architecture. Therefore, in this article the novelty is associated not only with the results of creative process, but also with main technological breakthroughs. One of them is industrialization and prosperity of experimental technology of monolithic reinforced concrete (further in the text referred to as "MRC") in Lithuania signifying the breakthrough of novelty and liberation from standardized forms. The other - influence of digital technologies on the novelty of artistic forms, which is related to integration of sustainability ideas, transfer of analysis of biological processes and forms to architecture, and is manifested through light, complex curvilinear spatial and surface structures. Contemporary architecture is dated from the second half of the $20^{\text {th }}$ century up to the beginning of the $21^{\text {st }}$ century in this text.

Different methods of analysis are used to reveal complex phenomenon of the novelty in contemporary architecture. The theoretical basis is formed analytically, using text interpretation method; utopian ideas and experimental development aspects are revealed by historical analysis. Comparative analysis is used for foreign and Lithuanian contemporary architectural ideas parallels showing a kindred connection of ideas. The survey is conducted in principles of inductive (bottom-up) and deductive (top-down) analysis - from the individual facts available to generalizable knowledge, and vice versa from the common, universal knowledge to the individual characterization.

\section{CONCEPT OF NOVELTY}

Novelty in architecture theory and philosophy is associated with metamorphosis [12], [13], [15], [16], becoming somebody/ something else, different-as alternative to tradition and dominant order. Thus the novelty here may be defined in other words, such as radical alternative, otherness, original, unexpected, utopian and experimental. Novelty through metamorphosis (becoming, change) is also emphasized by philosophers Gilles Deleuze and Felix Guattari; according to them, novelty is inspired by nomadism and functioning of the war machine [16, 87-93], [10, 185-188]. "War" accompanies any creative process aimed at generating a new, innovative, different form, as it rejects any settled opinion or rules imposed by ideology, and signifies an escape, a liberating motion. In other words, creation contributes to unfolding the fold - other, new world. Generally speaking, a fold, according to Deleuze, is like a new concept of time and space reflecting the complexity of our times [10, 109-110], and novelty is achieved by deconstructing traditions or using their certain sets, collages. Such qualities are characteristic to network structures (so-called "rhizomes" or "multiplicities systems"), which do not have any centre, hierarchy, regulation or representation, are tend to spread in all directions and also represent a specific feature of a collage (as a set of separate accidental parts conveying a certain character). This concept is very close to the functioning principles of digital technologies and computers.

According to Lithuanian philosopher Bronius Kuzmickas, novelty and tradition are inseparable elements of culture [8]. Every culture has its own primary ideological sources, such as myths and religion, based on which the world and human life are explained, but the content of such sources is in constant transformation. In general, it can be stated that multiplicity, rejection of hierarchic systems and the network, complex, folder-shaped structures formed according to the principle of 

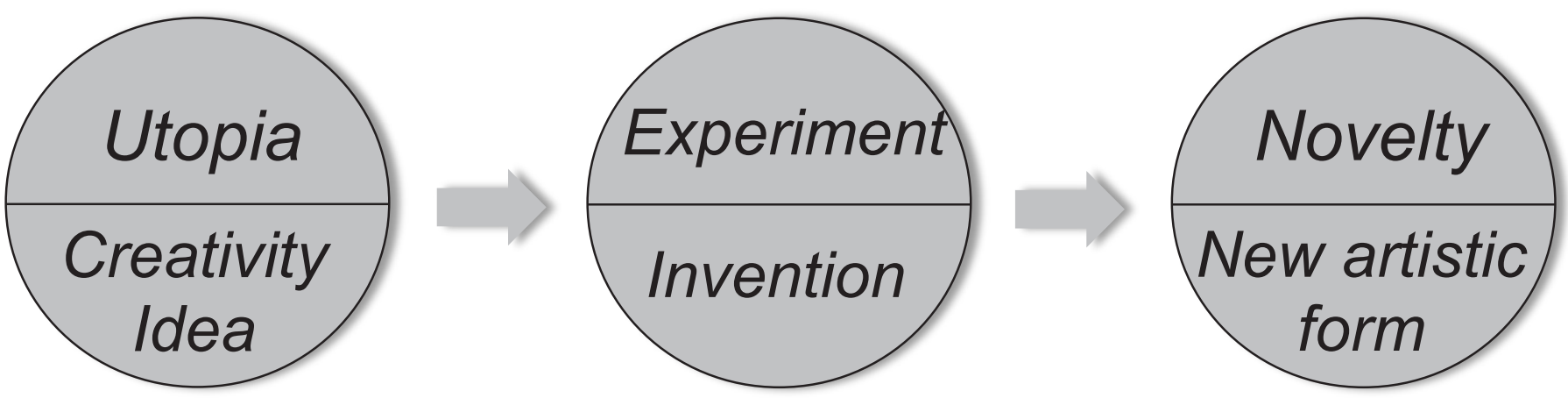

Fig. 1. Conception of novelty.

collage are characteristic features of contemporary novelty.

As mentioned before, a vital element for every culture is mythology that depicts human and spatial transformations, becoming someone/something else, new. And this is inherent not only in the Classical Antiquity, but also modern mythology, which is manifested through science fiction movies, books, video games and vanguard picturing the search for the new, perfect world, perfect society [12]. It means, that besides constant elements (archetypes, values) exist shifting, new ones. In architecture such picturing of the new world is manifested through creative process, sketching conceptual ideas, utopian futuristic visions, with the use of free and unconstrained mind, rejection of any prejudice or intolerance to solutions "from the top". According to Tomas Grunskis, architectural creation may be also defined as experimental architecture, which in an innovative way solves the issues of method, form and technology in architecture [4]. While analysing the concept and typology of experimental architecture, he distinguishes two types of such architecture -idealistic and realistic. The first has no intention for realization and is designed for dissemination and maintenance of ideas, which often are associated with social criticism of the time or utopian image of the new society; the second can be defined as practical, orientated towards realization $[5,161]$.

Therefore, another important moment for novelty is the method of experiment applied in testing of new actions, techniques, technologies or combinations of them, without being aware of the possible result. By its nature, experiment rejects the past, examines the compatibility of different elements and their effect, in other words, it constructs new and interesting combinations, therefore it is inseparable from innovation, discoveries and generation of novelty.

In summary it can be stated that the search for novelty in the art of architecture is manifested on several levels, such as pure conceptual level - through utopian ideas, future visions, creation of the "new" world which reflects a particular worldview (social, cultural, political, etc.); and actualization level, where a concept is materialized, obtains an innovatory form - new artistic form often through implementation of different experiments related to construction and computation technologies or by use of scientific inventions.

\section{UTOPIA AND EXPERIMENT}

"Utopia" (derived from the Greek ov "no"+ "no place") as defined in the Dictionary of International Terms means "phantasy", "fiction", "unfulfilled dream". To mention a few, the most outstanding literary utopias it would be: Plato's Republic, considered to be one of the first utopian treatises in the world; famous Thomas More's Utopia (1516); and William Gibson's Neroromancer (1984), in which virtual cyber space is described for the first time. Since its first appearance, utopia was more of a literary genre, but in the $19^{\text {th }}$ and $20^{\text {th }}$ centuries it became a synonym for social movements and experiments with the image of the new world, because utopia needed specific characterizations, such as streets and buildings thus the visualisation of the need for social changes obtained a spatial shape [11]. Such attempts in architecture were manifested by utopian ideas of French Étienne-Louis Boullée, Claude-Nicolas Ledoux and Jean-Jacques Lequeu (the end of the $18^{\text {th }}-$ the beginning of the $19^{\text {th }}$ centuries), who applied abstract geometric forms, large scales, endless rhythm and decreasing number of details. According to A. Picon, in the $20^{\text {th }}$ century, social utopian ideas and experiments with the new world's image in architecture become symmetrical in Europe. It could be illustrated by sketches of Italian futurist Sant'Elia (see in Fig. 2a) picturing huge monolithic skyscrapers, industrialized and mechanised city of the 1920 s or the utopian ideas of the 1950s. The creators of latter ideas, drew inspiration from Sant'Elia's sketches; which were soaked with irony towards the already existing technology-based new world, modular construction experiments. They especially emphasized motion, flexibility and transparency. Most outstanding examples could be the light structure of Geodesic Dome by R. Buckminster Fuller (see Fig. 2b) and Dymaxion House (1930), the prototypes of energy saving solutions; Archigram's project Walking City (see in Fig. 2c). The latest conception of novelty, relationship between utopia and architecture, is related with rapid development of digital technologies, which started by the end of the $20^{\text {th }}$ century and is associated with biotech [1, 233-245] ideas in architecture, concepts of eco-friendly, sustainable architecture and analysis of nature forms and processes, such as autopoiesis [14, 1-4] or morphogenesis [9, 32] (see Fig. 2d), 

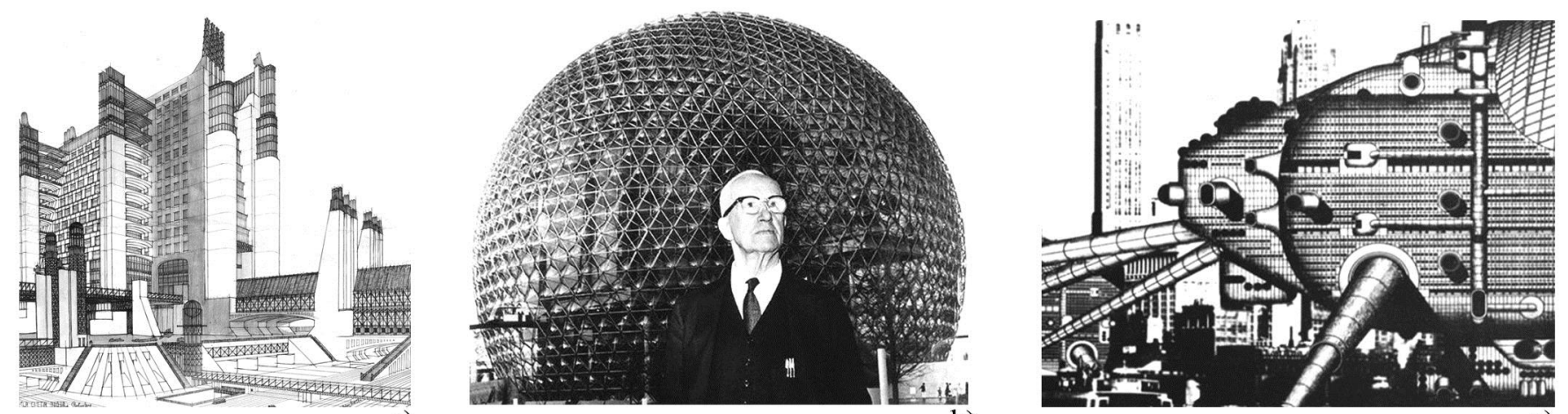

b)
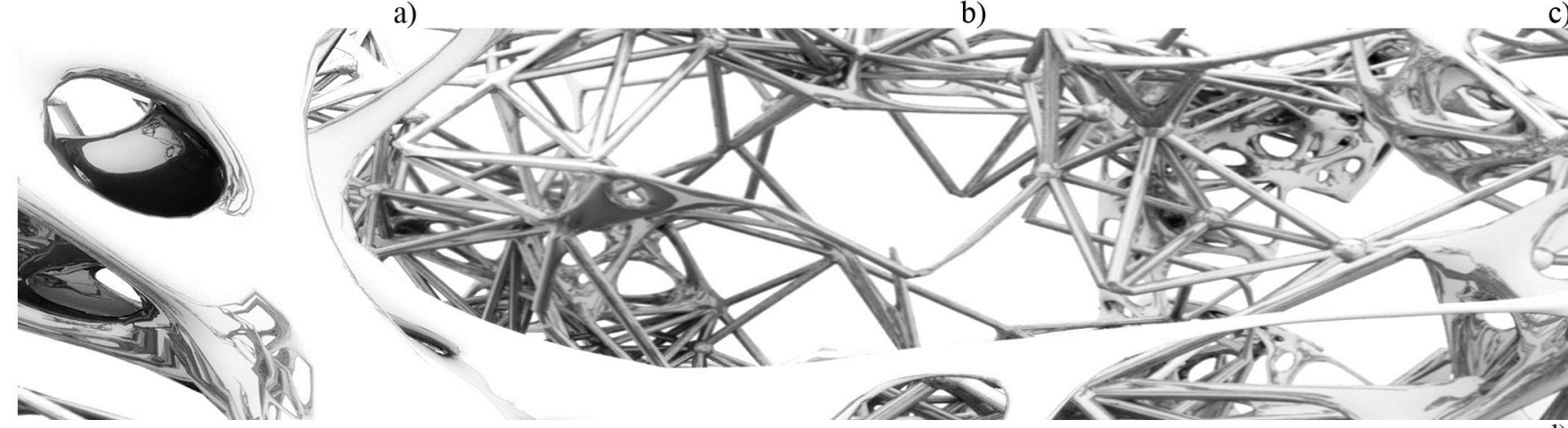

Fig. 2. Utopian ideas in Europe: a) La città nuova by Antonio Sant'Elia (1914); b) Geodesic Dome by R. Buckminster Fuller, about 1950; c) Walking City by Ron Heron (Archigram) (1964); d) Fragment of morphogenetic structure by Jon Bailey (2011).

as well as experiments with $\mathrm{CAD} / \mathrm{CAM}$ (computer-aided design / computer-aided manufacturing including robots) technologies [1, 75-79]. Integration of computer software into the creation process becomes an important tool and stimulates experiments and appearance of new artistic forms. For example, in the second half of the $20^{\text {th }}$ century Charles Jenks associates the novelty of architectural forms with compositions of fractals (a composition distinguished by its own symmetry on all scales), as well as compositions based on principles of waves, folds and bends [6, 12-16], and Patrick Schumacher relates the novelty of contemporary forms with biomorphic (complex curvilinear) shapes and shapes based on the principle of angular crystal structures [14, 1-4].

Evolution of content of utopian ideas in Western Europe also marks the metamorphoses of the novelty conception: the first half of the $20^{\text {th }}$ century is famous for ethic and aesthetic ideals, transparency, abstract forms, dynamism, emphasized machine shapes, dexterity, speed, the dichotomy of biology (human) and mechanization (industry) as typical for visionary architecture [15,9]. But when abstraction of the modernists' form and dominance of technology were doubted in the second half of the $20^{\text {th }}$ century, the concepts of complexity, multiplicity and building sustainability got in focus, artists, architects returned to the search of match and compatibility of biological and mechanized processes. Also, it reflects new worldview and new modern society, which according to Zygmunt Bauman is "Liquid Modernity", there a person can shift from one social position to another, there nomadism becomes a general trait of the modern man and traditions would be replaced by self-chosen ones [2, 23].

Dissemination of western utopian ideas in Lithuania, especially in the second half of the $20^{\text {th }}$ century, of course, is closely connected with the soviet ideology and restrictions of professional information. Architecture of mass construction industrialized in the soviet times is an obvious example of the use of ideology for formation of new identity - back then the socialist-modernist utopia was planned and recklessly implemented in Lithuania [3]. As contraposition to such ideology, Lithuania had any more significant group of utopians, as, for example, Group T of Tallinn's architects, but nevertheless some futurist visions were present in works of Lithuanian architects, which manifested in reflecting over or individually conveying western trends. Most often such visions were rendered in unimplemented competition projects, the so-called "paper architecture". One of the most interesting examples of the second half of the $20^{\text {th }}$ century visionary architecture was a competition project of a "walking" theatre (on tour) (Fig. 3a) [7]. Its prefabricated-modular, moving object of light structures resembles the ideas by Archigram or Fuller, or even liquid modernity.

Also noteworthy are a few variants of the Britanica Hotel in Kaunas by architect T. Paulauskas (1977), especially the variant of expressive wave and technologically progressive and aesthetically expressive proposal with sustained structures, 


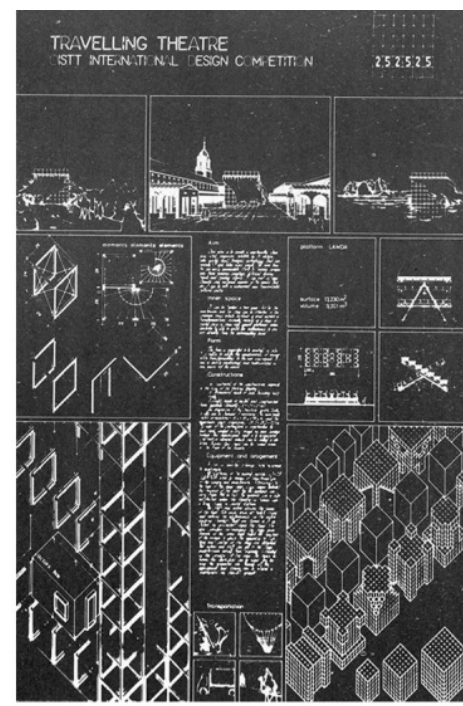

a)
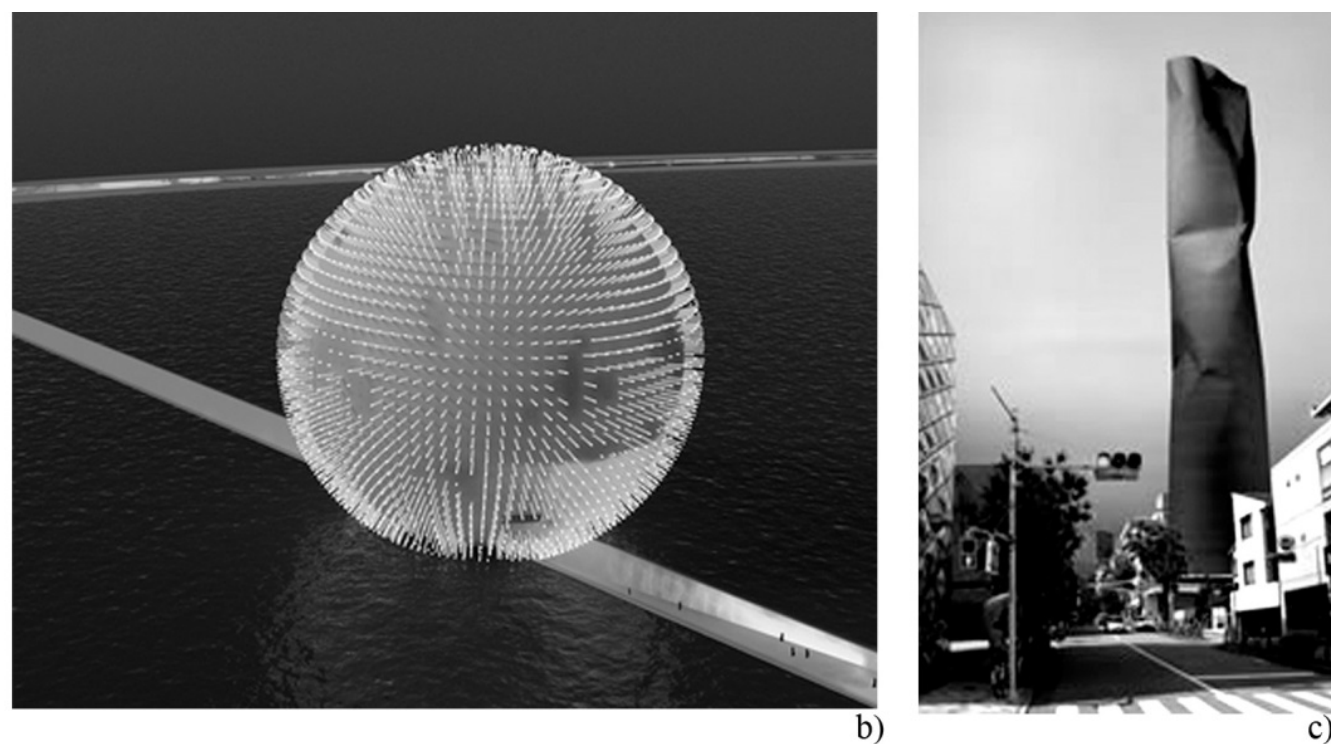

Fig. 3. Utopian ideas in contemporary Lithuanian architecture: a) Walking theatre by G. Aperavičius, R. Stasėnas and R. Krištapavičius (1984); b) World Sustainability Centre in the Netherlands by K. Lupeikis (2009); c) Fashion Museum in Tokyo by D. Čiuta, M. Pilvelis, V. Mažeikis and G. Auželis (2010).

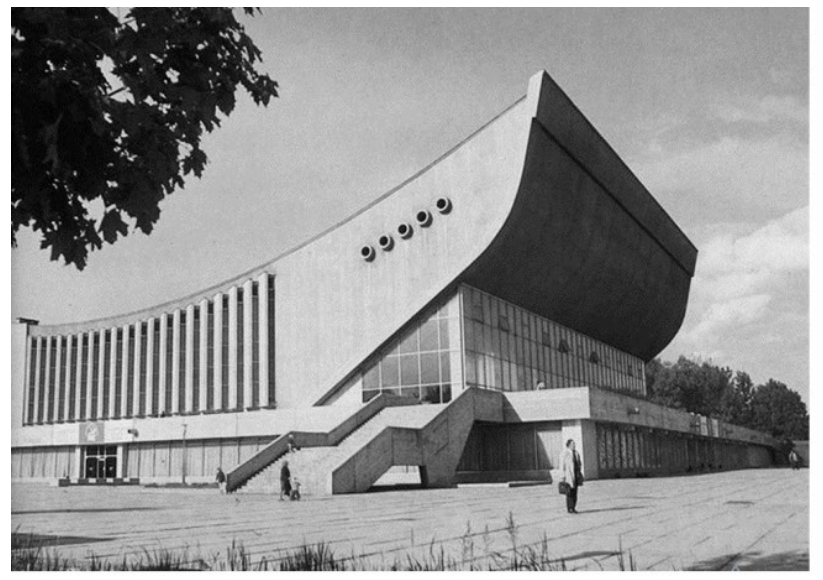

a)

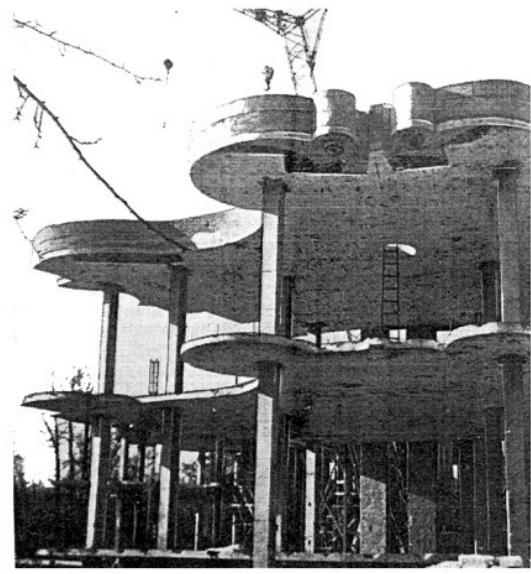

b)

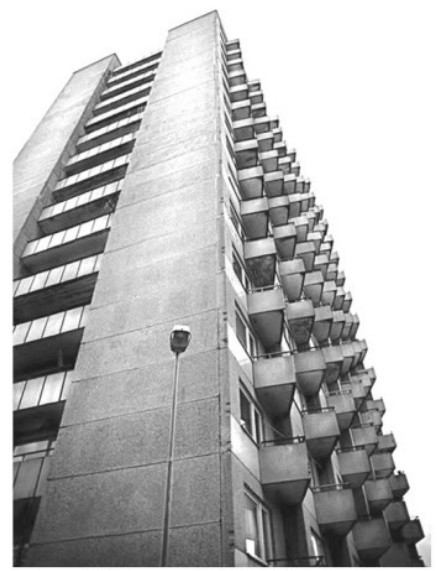

c)

Fig. 4. Examples of experimental architecture in the second half of the 20th century Lithuania: a) Vilnius Concert and Sports Palace building by architects E. Chlomauskas, J. Kriukelis and Z. Liandzbergis (1964-1971); b) fragment from Physiotherapy Health Resort Complex in Druskininkai by R. and A. Silinskai (photo of the construction site, 1977); c) 16 storey student dormitory building in Sauletekis, Vilnius by B. Kruminis (1974-1978).

which could have been the only object with such structure in Lithuania. They remained unimplemented due to their too complicated structural solution $[3,58]$. As far as the period after the restoration of Lithuanian independence is concerned, the futuristic design project of administration building in Klaipeda by G. Čaikauskas and N. Kupe (2003-2005) and K. Lupeikis’ proposal for the headquarters of the World Sustainability Centre (2009) should be mentioned. Although the shape of the proposed building had a form of primary geometric figure sphere (characteristic to utopians of the beginning of the $20^{\text {th }}$ century), but the needles on its surface functioned as optical fibres transmitting solar light inside and signified a certain transition towards the attitude of sustainable building and integrated design (Fig. 3b). The competition project of the Fashion Museum $N^{\circ} 113401$ in Tokyo by architects D. Čiuta, M. Pilvelis, V. Mažeikis and G. Auželis (2010) reflected the newest trends of artistic forms. The project won a honourable mention at the international architectural competition (Fig. 3c). The main idea of the project is constantly transforming, wrinkly surface of the building, which moves depending on the place and time, due to the wind, light, climate and temperature changes. The artistic form of the building is changed because of its integrated technological solutions - telescopic pistons responding to temperature and wind. The building obtains different form with every year, season, month, week, day, hour and even minute. The pits and bumps on the silhouette are illuminated with different colours - colour, as well as intensity of light, depends on the form of deformation.

Although conceptual ideas are very important for generating novelty and alternative thought, art of architecture and new artistic forms are inseparable from materiality and implementation. The method of experiment is very important 


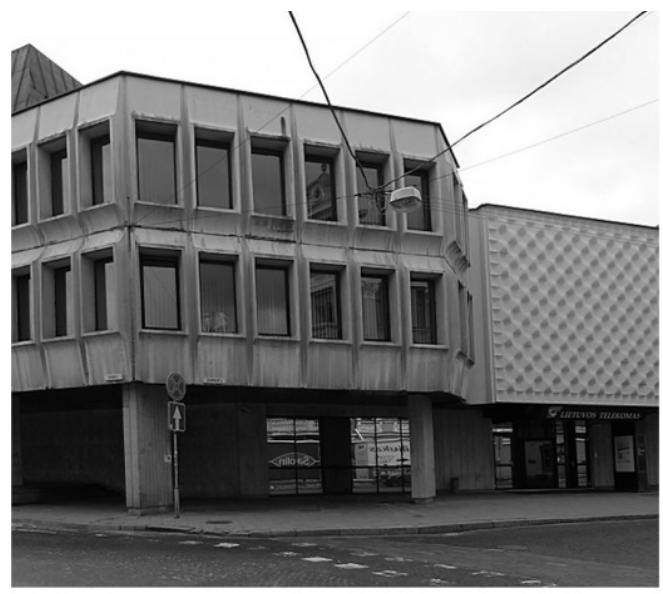

a)

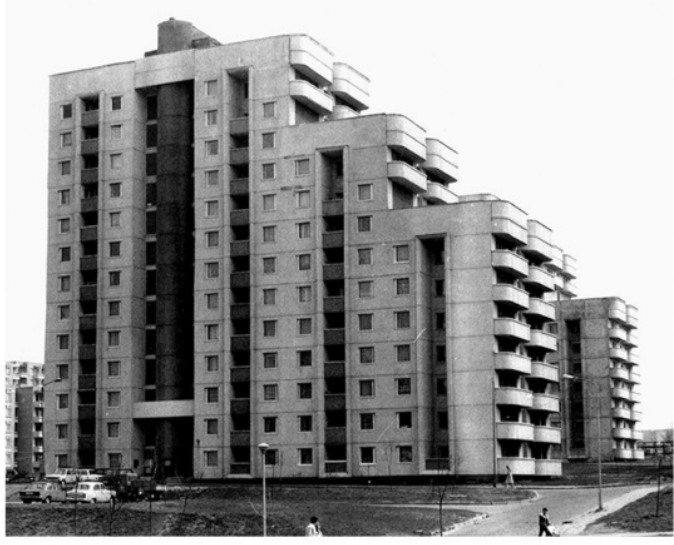

b)

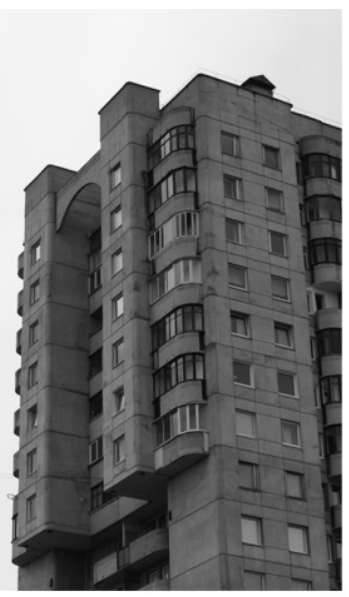

c)

Fig. 5. Examples of new artistic forms in contemporary Lithuanian architecture: a) Fragment of administration building of the Ministry of Communications of Lithuania by architect J. Šeibokas (1979); b) 7-13 storey apartment building in Justiniskes, Vilnius, by architect D. Ruseckas (1983); c) Fragment of the16-storey residential building, by architect R. Beinortas (1987).

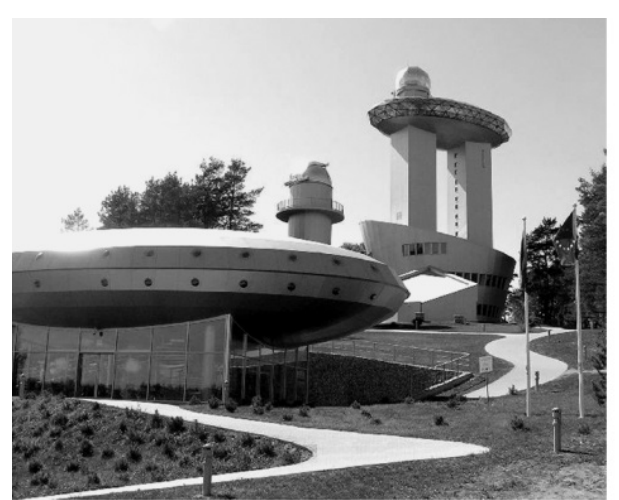

a)

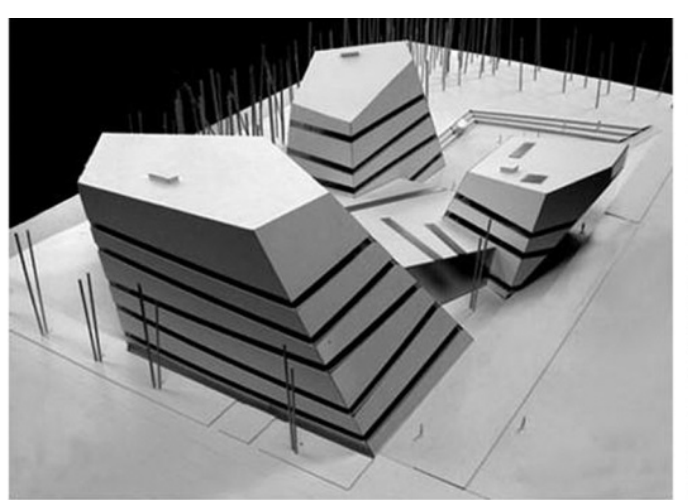

b)

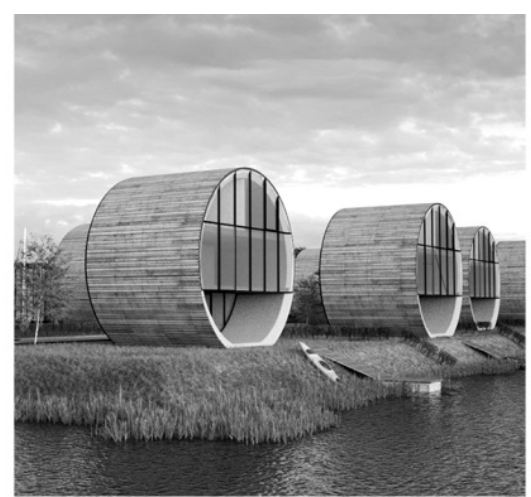

c)

Fig. 6. Examples of new artistic forms in contemporary Lithuanian architecture: a) Museum of Ethno-cosmology in Molètai, reconstruction architects V. Lisauskas, A. Gudaitis and R. Krištapavičius (1990-2009); b) Vilnius University Library by R. Palekas' studio (2011-2013); c) Rolling House in Svencele by Do Architects (2015).

here and is applied in order to check new and still untested ideas or their combinations. Therefore an experiment functions as a certain intermediate between utopia, conceptual idea and its realization, and is one of the basic catalysts of novelty of artistic forms.

Experiments with MRC technology in Lithuania should be considered probably one of the brightest examples of novelty and interaction between artistic form and technology within the second half of the $20^{\text {th }}$ century. In periodical press of the time, especially the magazine Statyba ir architektūra (19601990), one can find lots of headlines about experimental construction from spatial-modular blocks, possibilities of prestressed reinforced concrete, new technologies of double and single curvature shells (of complex bend, fold shape), span lifting method, etc. The brightest examples of implemented experimental design projects (the first in our country) are: the building of Vilnius Concert and Sports Palace with extremely innovative for its time single-curvature suspension roof structure (Fig. 4a); the first experimental high-rise residential blocks in Sauletekis, Vilnius (Fig. 4c) and subsequent residential high-rise construction from MRC with the use of different, improved technologies (1974-1990); the trefoil-shaped health resort complex in Druskininkai constructed according to the experimental method of uplift spans (Fig. 4b).

MRC buildings reflect free creation spirit, alternative to standardized, unified buildings - sharp angle boxes. Besides, MRC enabled easier experiments with artistic form, realization not only of rectangular-shaped houses, but also tectonic shells, folds, waves based on floral motives, experiments with surface textures.

By the end of the $20^{\text {th }}$ - beginning of the $21^{\text {st }}$ century new shifts of qualities of artistic form can be traced, for example, integration of historical elements, such as arches, columns, gables, into contemporary forms with creation of interesting artistic form of collages; integration of ideas of complexity and sustainability into the design process. The most remarkable for such collages of forms are the building of the Ministry of Communications in Vilnius (Fig. 5a); a high-rise residential 


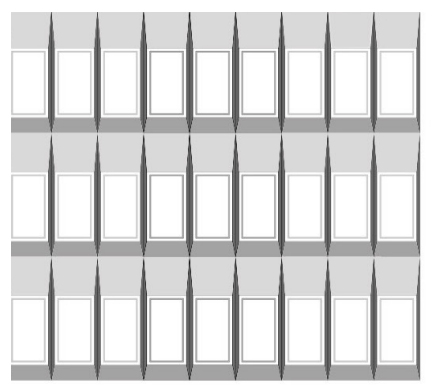

a)

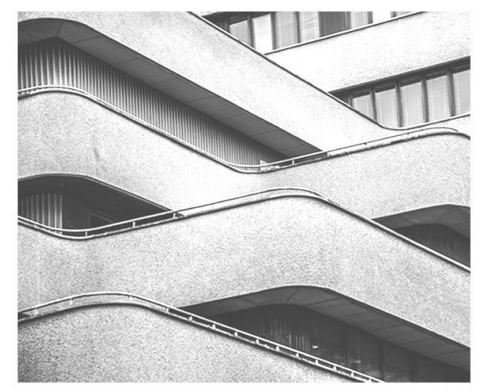

b)

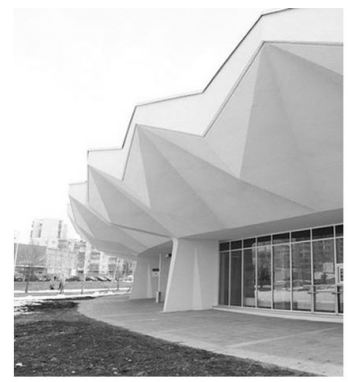

c)

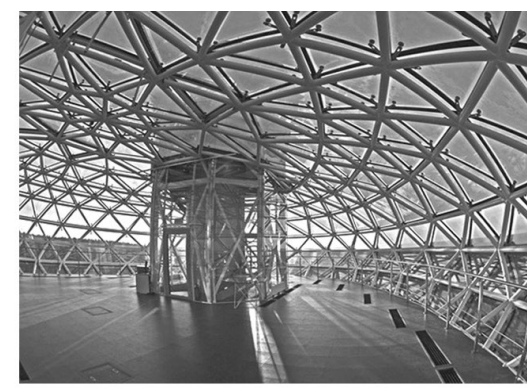

d)

Fig. 7. Main examples of new artistic forms in contemporary Lithuanian architecture: a) Fragment of modular elements; b) Fragment of waves; c) Fragment of folds; d) Fragment of curvilinear light structure.

TABLE I

NOVELTY INDICATORS, VISUAL EXPRESSION AND TECHNOLOGY MATRIX [AUTHOR OF THE ARTICLE]

\begin{tabular}{|c|c|c|}
\hline Quality & New artistic form & New technologies \\
\hline Transparency & $\begin{array}{l}\text { Elevated and transitive ground floor; } \\
\text { Glazed vertical }\end{array}$ & \multirow{5}{*}{$\begin{array}{l}\text { Construction technologies: } \\
\text { Spatial framework structures; } \\
\text { Complex shell structures. }\end{array}$} \\
\hline Motion/dynamics & $\begin{array}{l}\text { Stepped forms; } \\
\text { Fold and wave compositions; } \\
\text { Reiterated rhythm compositions; } \\
\text { Non-parallel line compositions }\end{array}$ & \\
\hline Lightness & $\begin{array}{l}\text { Detached surface; } \\
\text { Structural dome; } \\
\text { Curvilinear, "lace" type forms }\end{array}$ & \\
\hline Complexity/multiplicity & $\begin{array}{l}\text { Fractal composition; } \\
\text { Fold and wave composition; Collage / set of forms }\end{array}$ & \\
\hline Sustainability & $\begin{array}{l}\text { Integrated artistic form; } \\
\text { Complex forms }\end{array}$ & \\
\hline
\end{tabular}

house in Pašilaičiai, Vilnius, with fragments of an arch motive, gable on the roof and community services centre foreseen on the ground floor (multi-functionality) (Fig. 5c); and bringing nature towards people and technologies reflected in the first stepped 13-storey residential building in Justiniškès, Vilnius (Fig. 5b).

The impression of lightness, hovering over the earth, the ideas of Archigram's Moving City or Koolhaas' Underground City, collision of mythological, virtual world with the actual one are illustrated by one of a few buildings of the type in Lithuania the Museum of Ethno-cosmology in Moletai. Two towers with a spatial, light-structured capsule at the height of 32 meters, the main entrance node with a spatial ellipsis and underground passage-gallery (reflecting utopian underground city ideas) are composed on the expressive landscape (see Fig. 6a). The building of Vilnius University library in Vilnius by architect R. Palekas' team (2011-2013) is distinguished by architecture of non-parallel lines (Fig. 6b). The proposal of Rolling Houses in Svencelè by architects A. Baldišiūtè and A. Neniškis (2015) (Fig. 6c) should also be mentioned here.

\section{INDICATORS OF NOVELTY}

Presented in the article examples of competition and implemented design projects reflect the metamorphoses of Western European utopian ideas and experimental architecture, and, at the same time, changing concept of novelty qualities. These qualities could be distinguished as novelty indicators which are revealed in visual form and could be named as follows:

1. Transparency;

2. Motion/dynamics;

3. Lightness;

4. Complexity/multiplicity;

5. Sustainability.

Transparency is disclosed through popularisation of ethic and aesthetic ideas, elevated and transitive ground floor and large 
glazed surfaces in a building, reveals open and lucid society. Motion and action is revealed through modular prefabricated forms, which signify speed and denial of hierarchy; through projecting/protruding "moving" forms such as staircases and elevators and making them of rounded shapes; through wavy, broken forms, endless rhythm, non-parallel volumes and diagonal columns, transformable spaces. The feature of lightness is manifested by different framework structures, detached façade surfaces. Complexity and multiplicity are manifested by forms made according to the principles of collage, fractal, fold, wave and crystal referring to the complexity of nature. Sustainability unifies all of the aforementioned qualities and is a basic novelty indicator in contemporary architecture. Sustainability has in itself the process of integrated (smart)-conceptual designing and updating, bringing closer the biological and technological pole. Building sustainability ideas are integrated from the beginning of designing process on the concept level - while selecting a plot for building, form according to the cardinal points, materials, construction and design technology. Sustainability ideas, such as use of alternative energy resources, recycled materials, innovative technologies, must be integrated in order to develop good microclimate in the premises and reduce the maintenance costs. Such qualities are characteristic to the first "green" administration building with double glazed facades, twelve-storey ellipsis-shaped Green Hall in Vilnius, by Danish architect Steen Enrico Andersen (PLH arkitekter) and Gintautas Blažiūnas (Archprojektas) (2011).

\section{CONCLUSION}

1. The concept of novelty is closely connected to metamorphosis, becoming something/somebody else, alternative solution for the majority and with changing shifts in worldview. Novelty in architecture is manifested through creative process and experimentation, which signify liberation from standards and stagnant dogmas.

2. Novelty, beside archetypal ones in architecture, is manifested on several levels: the conceptual level - by utopian ideas, futuristic visions, creation of the "new" world; and the actualization level when a concept through experiment obtains an innovative material artistic form or even a new typology of the buildings.

3. Novelty in Lithuanian art of architecture is manifested in solutions of different competition projects, which were never implemented, and on the level of experimental design and realization.

4. In the beginning of the $20^{\text {th }}$ century, novelty of artistic forms was associated with abstract forms, construction modularity, transparency, motion and speed demonstration possibilities in architecture, and in the middle of the $20^{\text {th }}$ century the notion of novelty was supplemented with the concepts of lightness, complexity, multiplicity and building sustainability; matching and conforming the biological and mechanized processes were revised.

5. Formulated indicators for recognition of novelty qualities of artistic forms distinguished also new visual expressions of artistic forms characteristic to contemporary Lithuanian architecture. Spatial-modular, wavy, non-parallel line, foldershaped forms and forms of complex curviness could be referred to as such new artistic forms.

6. Integration of sustainability ideas into the conceptual and actualization processes signifying attempts to ally nature and industrialization, art and technology. Thus the main challenge for contemporary architects matches the requirements raised to the artistic expression and sustainability of a building, employing the possibilities of computational design and form simulation software.

\section{REFERENCES}

1. Abel, Ch. Architecture, Technology and Process. Architectural Press, 2004, p. 77-155, 233-245.

2. Bauman, Z. Liquid Modernity. London: Potily Press, 2000. 23 p.

3. Drẻmaitė, M., Petrulis, V. Modernizmas sovietinejje Lietuvoje : utopijos gimimas ir žlugimas. Modernizmas tarp nostalgijos ir kritiškumo, ALF 02, 2014, p. 53-68.

4. Grunskis, T. Kūrybinio eksperimento sampratos architektūroje Urbanistika ir architektūra, Vol. 35, Issue 1, 2011, p. 21-27.

5. Grunskis, T. Kai kurie eksperimentinès architektūros tipologinès raidos ypatumai. Urbanistika ir architektūra, Vol. 35, Issue 2, 2011, p. 159-168.

6. Jencks, Ch. The Architecture of the Jumping Universe. London: John Wiley \& Sons Ltd, Revised edition, 1997. 192 p.

7. Jaunuju architektu katalogas [S. Kuncevičius ed.]. Vilnius: MSPI, 1984. $51 \mathrm{p}$.

8. Kuzmickas, B. Tradition and Innovation from the Point of View of Modernity and Postmodernity. Logos, Vol. 67, 2011, p. 6-15.

9. Leach, N. Digital Morphogenesis. Architectural Design, Vol. 79, Issue 1, 2009, p. 32-37. http://dx.doi.org/10.1002/ad.806

10. The Deleuze dictionary [A.Parr ed.]. Edinburg: Edinburg University Press, Revised edition 2010. 337 p.

11. Picon, A. Learning from Utopia : Contemporary Architecture and the Quest for Political and Social Relevance. Journal of Architectural Education, Vol. 67, Issue 1, 2013, p. 17-23. http://dx.doi.org/10.1080/10 464883.2013.767120

12. Pihl, O. Place no place : Aspects of the origins or the virtual architecture exemplified through science fiction films. Aalborg: Axis Mundi Art Press, 2008. $256 \mathrm{p}$.

13. Mažeikis, G. İsikitinimai : sąmoningumo metamorfozès. Kitos knygos, 2013, p. 36-45, 121-131.

14. Schumacher, P. The Autopoiesis of Architecture. NY: John Wiley \& Sons Ltd, 2011. 480 p.

15. Spiller, N. Visionary Architecture. London: Thames \& Hudson LTD, 2006. 9 p.

16. Žukauskaitè, A. Gilles'io Deleuze'o ir Felixo Guattari filosofija : daugialypumo logika. Vilnius: Baltos lankos, 2011. 272 p. 


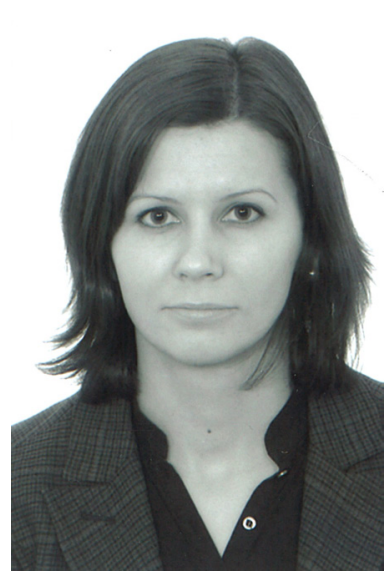

Aušra Černauskienė was born in Šiauliai in 1980. She received the degree of Bachelor of Arts in architecture in 2003, and Master of Arts in architecture in 2005, from Vilnius Gediminas Technical University. Since 2013, she has been a PhD student with the Faculty of Architecture, VGTU. She is working on her doctoral thesis Interaction of New Artistic Forms and Technology in Contemporary Lithuanian Architecture under the supervision of scientific advisor Dr. Vytautas Petrušonis. Since 2006, she has been a certified architect with D. Ruseckas' architects studio. She has been a co-author of seven implemented public and residential buildings, participant of different creative workshops and competitions in Lithuania and abroad. She is the author of several scientific articles. Her research area is impact of innovation technologies on visual expression of architectural artistic forms and creative process.

She has received the following awards:

- Honourable mention for the project The Point, Tallinn Biennale (TAB) Recycling socialism, 2013;

- Laureate of the creative workshop for reconstruction of the Resurrection Square in Šauliai and generating and idea for a monument to honour the defenders of freedom and independence of the nation, project $\mathrm{i}+\mathrm{a}^{2}, 2010$.

\section{CONTACT DATA}

\section{Aušra Černauskienė}

Department of Architectural Fundamentals and Theory,

Vilnius Gediminas Technical University

Address: 26/1 Pylimo Av., Vilnius, LT-01132, Lithuania

Phone: +370 65209042

E-mail: ausra.cernauskiene@vgtu.lt 